\title{
Mõistatuste kogumine Eesti Kirjameeste Seltsis aastatel 1872-1893
}

Rein Saukas

\begin{abstract}
Teesid
Eesti mõistatuste süstemaatiline kogumine ülemaalise vabatahtlike kaastööliste võrgu kaudu algas Eesti Kirjameeste Seltsi asutamisega 1872. a. Artiklis on kogumistöö jagatud ulatuse ja juhtide (Jakob Hurt, Mihkel Veske, Jaan Jõgever) põhjal kahte oluliselt erinevasse perioodi, kusjuures mõlemad sisaldavad omakorda alaperioode. Kogumistööle kutsuti avalike üleskutsetega, tulemustest anti aru seltsi koosolekutel ja ajakirjanduses. Parimatele kogujatele kingiti raamatuid. Mõistatusi saatis 14 kihelkonnast 27 kogujat, enim Saaremaalt. Kokku saadeti 2139 mõistatust, mis on valdavalt autentsed, kirjakeeles, väheste murdejoontega.
\end{abstract}

Märksõnad: Eesti Kirjameeste Selts, Jakob Hurt, mõistatused, rahvaluulekogumine.

Käesolev artikkel põhineb mõistatuste saadetistel Eesti Kirjameeste Seltsi (EKmS) kogus ning neid toetavatel arhiivimaterjalidel, nagu korrespondentide (kaas)kirjad jms. Läbi on vaadatud teemat käsitlev trükisõna (ajaleheartiklid, seltsi koosolekute protokollid aastaraamatutes), et leida vähimaidki notiitse mõistatustesse puutuva kohta. Teemaga töötades tuli ilmsiks mitu kogumisloolist, kahe silma vahele jäänud seika, mis ei kajastu Vaina Mälgu uurimuses Eesti Kirjameeste Seltsi osa eesti folkloristika arengus (Tallinn 1963) ega ka mõistatuste akadeemilises väljaandes. Nendele on siis artiklis või selle kommentaarides tähelepanu juhitud.

Kogumistöö üldiseloomustus minu ülevaates toetub Vaina Mälgu monograafiale ja mõistatuste laekumist seltsi on jälgitud vastavalt V. Mälgu EKmSi rahvaluulekogumise periodiseeringule.

Artikli viimane osa käsitleb Mihkel Veske ja Carl Robert Jakobsoni rahvaluule kogumise alast tegevust 1870 . aastatel, mis on toonud arhiivi ka mõistatusainest. Nad ei saavutanud küll märkimisväärseid tulemusi, kuid ometi muutsid rahvaluule kogumise selle algaegadel mitmekesisemaks.

Rahvaluule kogumine Eesti Kirjameeste Seltsis alates asutamisest 1872. a kuni laialisaatmiseni 1893. a on jagatud ulatuse ja juh-

http://haldjas.folklore.ee/tagused/nr26/saukas.pdf 


\section{Rein Saukas}

tide (Jakob Hurt, Mihkel Veske, Jaan Jõgever) põhjal kahte oluliselt erinevasse perioodi, kusjuures mõlemad sisaldavad omakorda alaperioode.

\section{Mõistatuste kogumine Eesti Kirjameeste Seltsis Jakob Hurda juhendamisel aastatel 1872-1881}

\subsection{Kogumistööst aastatel 1872-1875 üldiselt}

Eesti Kirjameeste Selts (EKmS) asutati eesti rahvusliku liikumise kõrgajal 1872. a mitmeaastase ettevalmistuse tulemusena. Seltsi esimeseks presidendiks sai Jakob Hurt, kes oma varasemale 12-aastasele rahvaluulekogumise kogemusele toetudes asus peaaegu ainuisikuliselt ja kindlalt selle töölõigu etteotsa.

Eesti Kirjameeste Seltsi esimesele koosolekule 22. veebruaril 1872 saadetud kirjas ütleb J. Hurt:

Teaduse asjade poolest peaks Seltsi esimene pü̈̈dmine olema igal pool ja kõige jõuuga vanu Eestirahva mälestusi, iseäranis aga vanu Eestirahva laulusid ja

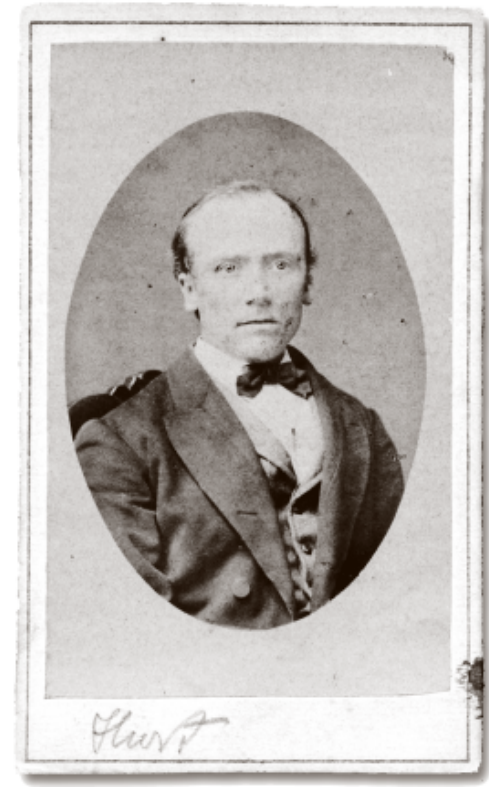

www.folkLore.ee/tagused regevärsisid rahva suust korjata ja kirja panna. Neil on, nõnda kui teame, oma suur hind ja tähendus, kui vana aega uurime ja Eestirahva vaimu loomu sügavamine tundma tahame õppida. Küll ei saa igal Seltsi liikmel enesel võimalik olema külasid ja talusid pidi käia ja laulusid korjata, aga iga liige võib keelamata teravaid noorimehi ehk muido sündsaid inimesi korjama kihutada. Kus ja millal tarvis, saagu teadmata inimestele ära seletatud, mis pärast vana rahva mälestusi kirja pannakse. [---]

Foto 1. Jakob Hurt, kogumistöö juht aastatel 1872-1881. Reinhold Sachkeri foto. Tartu (EKLA A 37: 686). 
Kui hoolsaste ja teravaste otsitakse, võib minu arvates igast kihelkonnast läbistikku 100 laulu veel saada ja see oleks üks ütlemata kaunis vara ja abi vana aja tundmiseks. Pü̈̈dku siis iga Seltsi liige teha, mis võimalik, et need esivanemate vaimu õiekesed unustuse kartusest päästetud saaksivad (EKLA, f 15, m $3: 1,11 \mathrm{p}-2)$.

J. Hurt suunas peatähelepanu laulude kogumisele, teised žanrid, sealhulgas mõistatused, jäid paraku veidi teisejärguliseks. Selts ega selle president eraldi üleskutset kogumistööks ei avaldanud, viidati vaid J. Hurda artiklile "Mis lugu rahva mälestustest pidada" 1871. a Eesti Postimehe lisalehes nr 26 ja 27. Kirjutises nimetab autor rahva mälestuste hulgas ka mõistatusi:

[---] neljandaks kõik märgoanded esivanemate vaimuharimise järjest ja nende mõistuse ja meele teravusest, nimelt kõik ennemuistsed jutud, rahva laulud ehk regevärsid, $m$ õ $i$ s $t$ a $t u$ s e d [minu sõrendus - R. S.], vanad sõnad, tähtsad kõnekäänud ja mõnesugused arvamised, kas loodud asjadest või muust, mis inimese südant liigutab ja teda mõtlema paneb [---] (Hurt 1989: 9-10).

Konkreetseid juhiseid kogumistööks (kellelt koguda, kuidas koguda, materjali ülestähendamine jne) veel ei antud. Seda arutati küll seltsi kolmandal koosolekul, mille protokollis fikseeriti:

Peeti nõu Eesti vana vaimuvara korjamise viisi üle. Otsuseks jäi: korjamise viis muudab ennast aja, asja, inimeste, koha, ammeti ja korjajaga; jäägu seepärast iga mõistliku oma määrata (EKmSi protokollid 1873a: 79).

Neljandal koosolekul kõneles president uuesti seltsi ülesannetest ja pani paika kogujate ringi: Materjali koguda võib igaüks $(\mathrm{EKmSi}$ protokollid 1873b: 80).

J. Hurt hakkas peaaegu kõikidel seltsi koosolekutel tegema juttu rahvaluulekogumisest, selle töö tähtsusest, nimetama konkreetselt kogujaid ja nende saadetud materjali. Juba teisel koosolekul teatas ta esimestest laekunud saadetistest. Mõistatusi on esmakordselt nimetatud alles viiendal koosolekul 2. jaanuaril 1874:

C. Allas on üle selle veel suure hulga mõistatusi, vanusõnu ning muud tähtsat vanavara Seltsile Saaremaalt saatnud (EKmSi protokollid 1875a: 72). 


\section{Rein Saukas}

Kogumistööd juhendas ja propageeris J. Hurt ka kaastöölistega peetud kirjavahetustes, samuti muudes neil aastail peetud kõnedes, nagu "Mis Aleksandri koolile vasta pannakse ja mis selle pääle kosta" (1872), "Eesti päevaküsimused" (1874) (Hurt 1939: 106-148; 149170).

\subsection{Mõistatuste kogujad ja saadetised}

Kui vaadelda mõistatuste kirjapanemist neil aastail, siis tuleb kõigepealt kõnelda Rudolf Kallasest ja Carl Allasest. Rudolf Kallas oli 1871-1875 Tartus algkooliõpetaja ja seltsi kirjatoimetaja. Ta õhutas kogumistööle ka oma onu, Karja kihelkonnakooli õpetaja ja köstri Carl Allase, kes asuski Saaremaal üsna energiliselt tegutsema ise koguma ja oma tuttavaid sellele tööle suunama. Allase kogumistöö kohta ilmus juba 1872. a ajalehes artikkel (R. G. K. 1872). Vähemalt mõistatuste osas on saak olnud üsna suur. Kogumistööle on asutud kohe pärast seltsi vastavat palvet, sest kõik EKmSile

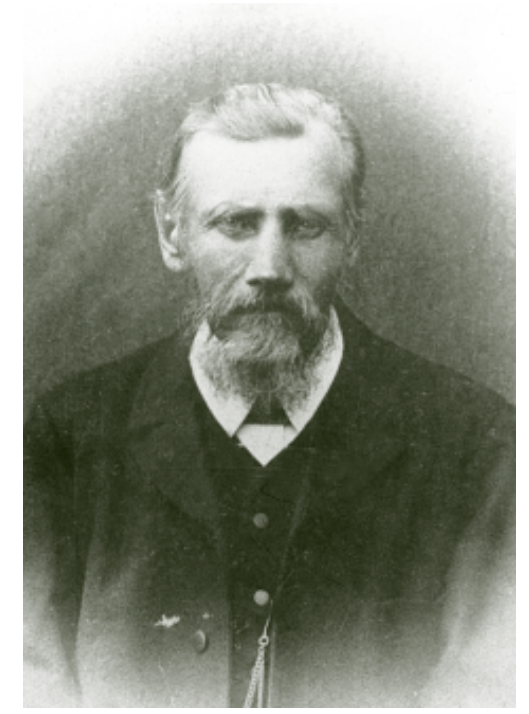

Foto 2. Carl Allas (EKLA, A 37: 3052).

www.folklore.ee/tagused

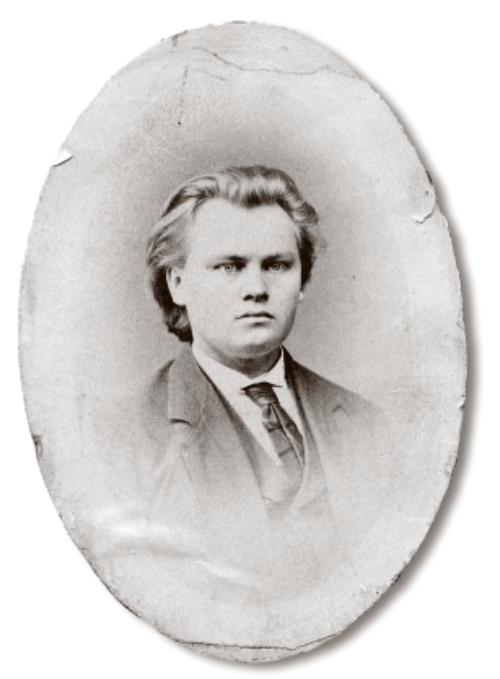

Foto 3. Rudolf Kallas 1872. a. Reinhold Sachkeri foto. Tartu (EKLA, A 63: 423). 
saadetud ja 1872. aastaga dateeritud mõistatuste kirjapanekud on tehtud saartelt, s.o Kallase-Allase ringi kogujate poolt. Siin tuleks esile tõsta kaht korjandust.

Üheks mõistatuste kirjapanijaks oli pseudonüümi O. T. K. taha peituv talupoeg, kes paneb oma 38 punktist koosnevale kogule pealkirjaks "Mõistatused. Tähendused" ja lisab:

Teäda on muidugi, et ma neid keiki ei mõista, aga nii palju, kui ma tean, tahan ma teile kõnelda (H I 4, 550).

Koguja kirjapanekud esindavad ehtsat Muhu traditsiooni, mõistatustes on haruldasi murdesõnu, nt käibib ainult Muhus O. T. K. mõistatuste kirjapanekus ettetulev tahilabidas 'labidas leivale lisatavate aganate peenendamiseks'. Ferdinand Johann Wiedemann on vähemalt 16 korral kasutanud O. T. K. teksti oma väljaande Aus dem inneren und äusseren Leben der Ehsten (1876) koostamisel, nt EM 283 B $_{1}$ a, EM 670 A $_{1}$ a, EM 691 B, EM 1072 I, EM 1446 Njne. Saadetise lõpus vabandab koguja:

Oh armas Isand C. A. [Carl Allas - R. S.] [---] Ma olen rumal talupojamees, mu mõistus on napp. Ma kirjutan mõne aasta kohta mõned pookstavid, mu käsi on vilumata [---] (H I 4, 552 ).

Mõistatuste varasest kogumisperioodist on $\mathrm{O}$. T. K. veenev näide selle kohta, et ka vähese haridusega kaastööline võib head ainest kirja panna.

Teine suurem kogu on Rudolf Kallase õelt Ida Kallaselt, kelle korjanduses pealkirjaga "Rähtsel" leidub tekste saaremaalistest tüüpidest, nagu Kass ahjus, käpp väljas? Tatt ninast väljas (EM 592); Peuse mahub, pütta ei mahu? Härjavits (EM $1597 \mathrm{Ab}_{1}$ ). Ainult I. Kallase tekstiga on eesti mõistatuste akadeemilises väljaandes esindatud Valge põll, mustad ä̈̈red? Ake (EM 2376). I. Kallase korjandusest pärit tekste on F. J. Wiedemann oma raamatus kasutanud enam kui 20 korral.

Geograafilise päritolu määratlemisel on probleeme Rudolf Kallase enda suurema mõistatusteseeriaga (H I 4, 283-288), kus nt Pool siga, pool kuuske? Peahari (EM 1687) viitab Viljandimaa või PõhjaTartumaa materjalile, Papike paeus, lokike peas? Pütsik (EM 1536) hoopis laiema levikuga lõunaeestilisele tüübile. F. J. Wiedemann on ka tema tekste kasutanud (EM 2216). Nähtavasti on R. Kallase 


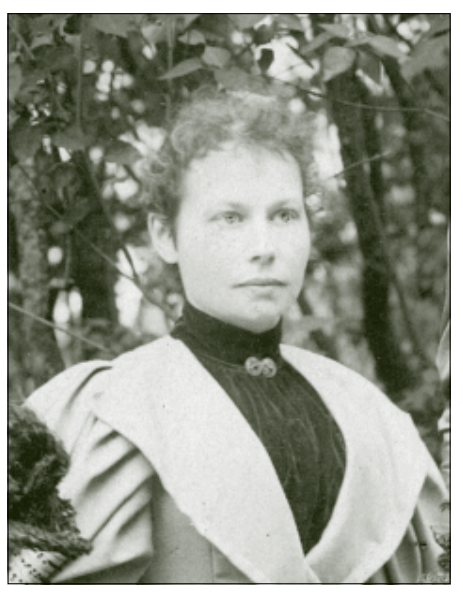

Foto 4. Ida Niggol (snd Kallas) u 1894. aastal. Wilhelm Stadeni foto (väljavõte grupipildilt EKLA, E 37: 85).

kogus leiduvad mõistatused üles kirjutatud eri paikkondadest pärit inimestelt, pealegi ei elanud ta tõenäolisel materjali kirjapanemise ajal Saaremaal.

Peab ütlema, et C. Allase ja R. Kallase abil laekunud rahvaluulematerjalidel, mis paiknevad köites H I 4 lehekülgedel 225-579, on suuri vormistuslikke puudujääke - kasinad on andmed kogujate, kogumisaja ja -paiga kohta. Materjale on nii mõnigi kord teiste isikute, nt Eduard Kallase poolt ümber kirjutatud.

Mujalt pärit üksikkogujatest tuleks eelkõige nimetada $\mathrm{EKmSi}$ asutajaliiget, Helme kihelkonna Patküla valla Soesaadu kooli õpetajat Aleksander Wahlbergi, kellelt on meieni jõudnud 10. detsembril 1874 dateeritud esinduslik 317 punktist koosnev alfabeetiliseltjärjestatud mõistatuste korjandus. J. Hurt on saadetise viseerinud 1875. a jaanuaris.

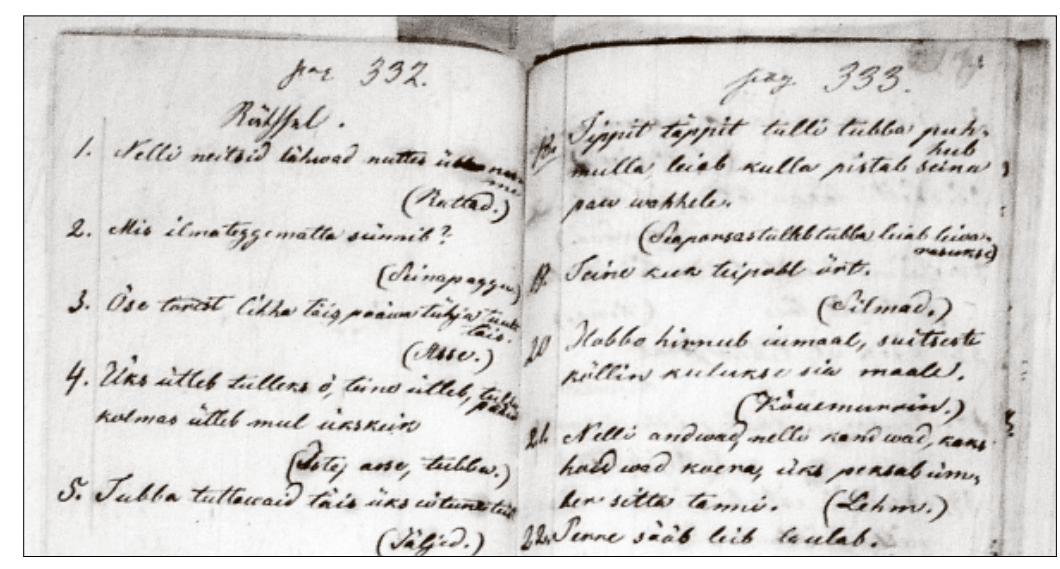

Foto 5. Ida Kallase mõistatuste korjandus. 1872 (H I 4, 332-333). 
Rein Saukas

Kaaskirjas 20. maist 1874 teatab koolmeister J. Hurdale: Siin leiate midagi vanust asjust kogutud olevat, mis siist ja säält rahvasuust kuulnud olen ja omas arvamises "Kirjameeste seltsile" tarviliku leidnud, misjärel teeb lähemalt juttu vanasõnadest ja juttudest. Tekstide kirjapanemise viisist kirjutab A. Wahlberg ise nõnda: [---] ja olen pü̈̈dnud seda nenda kõnelda, kuda vanem rahvas seda praegu veel taga järel räägib, mis nemad enne oma vanemadest kuulnud (H, R 3, 495). A. Wahlbergi üleskirjutused on üldiselt autentsed, võib-olla on küll kasutatud Otto Reinhold von Holtzi raamatut Luggemissed Eestima Tallorahva Moistusse ja Süddame Juhhatamiseks (1817). Materjalis leiab üksikuid näiteid ka väga kitsast kohalikust traditsioonist, nagu Kiberiku-käberiku, käpa urgu, joone urgu, soone urgu? Sõrmkinnas (EM 639) või Kolme kanti kuninga ait? Tatter (EM 715), mille levik piirdub Helme või selle lähikihelkondadega. Mõistatused on üles kirjutatud põhiosas kirjakeelsetena üksikuid murdejooni ja -sõnu kasutades (laulude üleskirjutused on aga valdavalt murdes). A. Wahlbergi materjalist teeb J. Hurt juttu seltsi seitsmendal koosolekul 8. jaanuaril 1875:

Selts tänab südamest kõiki neid mehi, kes on aega leidnud oma töö rägastustes ommeti veel ka ikka seda tarkust tähele panna, mis turude pääl hü̈̈ab; iseäralist tänu on Selts Wahlbergile tema rohke ja tähtsa vanavara kogumise eest võlgu (EKmSi protokollid 1875b: 93).

Kogumistöö esimestel aastatel saatsid mõistatusi veel EKmSi liikmed, Harju-Madise kihelkonna vallakooliõpetaja ja vallakirjutaja Gustav Johannes Treumann, kihelkonnakooliõpetaja ja köster G. Soo ning suurkoolis studeeriv pärastine kirikuõpetaja Johannes Kerg.

Sellesse perioodi saab arvata ka kolm anonüümset, originaalis

Foto 6. Gustav Johannes Treumann (Mälk, Vaina. Eesti Kirjameeste Seltsi ..., lk 79).

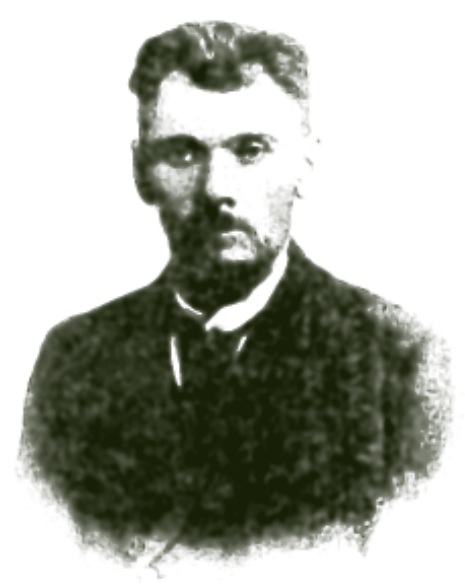




\section{Rein Saukas}

dateerimata mõistatuste saadetist (EKS $4^{\circ} 4,392-395$ (2-33); EKS $8^{\circ}$ 1, 348-349 (1-11); EKS 4º 4, 431-438 (1-66) \& H, R 5, 123-126 (67-114)). Viimane, 114 mõistatust sisaldav saadetis on kasutatud paberi eri formaadi tõttu või lihtsalt tähelepanematusest sattunud J. Hurdal kogu komplekteerimisel eri köidetesse. V. Mälk oma uurimuses ei ole registreerinud saadetise osa H, R 5, 123-126 EKmSi materjalide hulka. Ta paigutab nimetatud korjandused aastatesse 1876-1881 (Mälk 1963: 102-105), kuid mõistatuste akadeemilise väljaande koostamise käigus on selgunud, et F. J. Wiedemann on kasutanud neid kõiki oma raamatu Aus dem inneren und äusseren Leben der Ehsten mõistatuste osa kokkupanemisel. On üsna tõenäoline, et Saaremaa päritoluga käsikirjad on saadetud C. Allase korrespondentide ringist. ${ }^{1}$ Korjandus EKS $4^{\circ} 4,392-395$ on valdavas osas maha kirjutatud Friedrich Wilhelm Willmanni raamatust Juttud ja Teggud kui ka Monningad Öppetussed mis maia-piddamisse pärrast tarvis lähtvad... (1782), EKS $4^{\circ} 4,431-438$ \& H, R 5, 123-126 materjal pärineb oletatavasti Lõuna-Eestist ja on autentne.

Kuigi mõistatuste kogumisele eraldi tähelepanu ei pööratud, laekus sel perioodil kokku 927 mõistatust (vrd: rahvalaule oli 1076, jutte 189, vanasõnu ja kõnekäände 3132), nende kogujate ring oli siiski kitsas, hõlmates peamiselt seltsi liikmeid ja Carl Allase värvatud kohalikke kaastöölisi.

J. Hurda juhendamisel aastatel 1872-1875 EKmSis kogutud mõistatustest annab ülevaate ka tabel lk 186-188.

\subsection{Kogumistööst aastatel 1876-1881 üldiselt}

1876. aastat võib pidada rahvaluulekogumises uue perioodi alguseks, innustajana kindlasti Vana Kandle Põlva kihelkonna laulude 1. vihu ilmumine 1875. a. Et laulude avaldamine pidi toimuma kihelkondade kaupa, siis plaanis J. Hurt ka kogumistööd samamoodi. Tema kavatsusest saame jällegi aimu kirjavahetuse kaudu. Nii kirjutab J. Hurt 28. oktoobril 1875 C. R. Jakobsonile:

Meie peame asjaga nii kaugele jõudma, et igast kihelkonnast viimati võib ütelda: nüüd on kõik läbi uuritud ja suurt saaki pole siit enam leida (nimelt laulude poolest) (EKLA, f 47, $\mathrm{m} 2$ : $4,116)$.

Ja mõni kuu hiljem, 1. märtsil 1976: 
Minu pü̈̈dmine on nü̈̈, et igasse kihelkonda üks mees saaks, kes nagu käemeheks lööb, et sääl hoolega kõik veel kokku korjatakse ja midagi suurt järele ei jä̈̈ (EKLA, f 47, m 2: 4, l1).

Seltsis oli rahvaluulekogumine kõne all 1876. a juunis, kui kiideti heaks nõu igasse kihelkonda koguja leida ja selts palus trükitud sõna läbi igas kihelkonnas nooremaid teravaid mehi, et nemad niisuguse korjamise enese pääle võtaksivad. Ühtlasi jõutakse järeldusele, et üksi sedaviisi, kui igas kihelkonnas hoolega korjatakse ja nimelt igast kihelkonnast aasta kahe-kolme pärast ütelda võib: nü̈̈d on meie pool kõik nurgad ja kolgad vana laulude poolest ära uuritud ja puhtaks kaabitud, nii et suuremat leidu enam loota ei ole [---]. Vanavara paluti toimetada Kirjameeste Seltsi presidendi kätte Otepäässe, samas sooviti, et kogujad end Hurda juures üles annaksid ja tähendagu ka kui tarvis juure, mis nad ehk tasumiseks peavad nõudma, kui vaeva näevad (EKmSi protokollid 1877a: 71).

Juba 1876. a märtsis oli Eesti Postimehe lisalehes nr 13 ilmunud ka kogumistöö juhend ja rahvaluule publitseerimiskava "Eestirahva ajaraamat", ${ }^{2}$ mida võib pidada esimeseks põhjalikumaks kogumisjuhiseks kõikide rahvaluuleliikide kohta. Selle allosa "II. Vana Tarkus" hõlmab õpetlikka vanu sõnu ja mõistatusi (Hurt 1989a: 33). Täpsemaid juhiseid mõistatuste kirjapanemise kohta ei ole, küll aga vanasõnade osas.

Üleskutseid kogumistööks ilmus järgnevatel aastatel teisigi. 1878. a seitsme seltsi liikme allkirjaga "Avalik kiri kõigile" mitmes eesti ja ühes saksa lehes (Avalik kiri kõigile 1878).

Viimases üleskutses kutsuti ka raha annetama, et parematele kaastöölistele nende töö eest tasuda. Nagu eespool öeldud, oli tasust juttu ka seltsi 1876. a juunikuu koosolekul. Et kogumistöö eest on raha koguni küsitud, selle kohta leidub andmeid kirjavahetusest: kogujatele andis kindlasti julgust seltsi koosoleku sellekohane otsus. 10. aprillil 1878 kirjutab Frido Matson J. Hurdale:

Kui nü̈̈d aulik president seda mitte pahaks ega paljuks ei paneks, siis nõuaksin 6 [rubla] selle vaeva ja kirjutuse ette ja ühe rubla paberi kulu raha - see oleks siis 7 [rubla] (H I 4, 124).

Tegelikult on F. Matsonile makstud natuke rohkem, kui ta küsida tihkas - 8 rubla (EKLA, f 14, m 12: 13, l 36). Jakob Jagomann annab 30. mail 1877 kirjaga J. Hurdale seltsile teada: 


\section{Rein Saukas}

Nüüd või mina teile teedä anda, mes mina oma korjatu vanavaraga tee - mina mü̈̈ küll oma vana varanduse Kirjameeste Seltsile ärä. [---] Ja mina nõvva oma korjatu vanavara eest 25 vai 30 rupla (EKLA, f 43, m 6: 7, 1 5).

J. Jagomann on tasu saanud 1877. ja 1878. a kokku 30 rubla (EKLA, f 14, $\mathrm{m} 12$ : 13, 1 22, 39). 1878. a on kokku makstud vana laulude korjamise eest 103 rubla (EKmSi finantsaruanne 1879: 36). Raha on makstud ka Karl Moksile, kes kirjutab 20. detsembril 1886 Hugo Treffnerile:

[---] poisikesepõlves a. 1879 korjatud vanavara eest sain õp. $H$ [urda], selleaegse E.K.M.S. presidendi käest 8 rubla (EKLA, f 51, m 36: 1, l 180p).

Mõistatuste kogujatest on makstud kokku neljale isikule: need olid J. Jagomann, F. Matson, C. Allas, K. Moks.

Tasu maksmine ei olnud põhiline tunnustus tehtud töö eest. Seda osa täitsid ka saatjate nimetamine seltsi koosolekutel ja ajakirjanduses, isiklik kirjavahetus, seltsi väljaannete, eelkõige Vana Kandle vihikute saatmine. Viimase kohta leidub märge A. Wahlbergi kirjas J. Hurdale 28. märtsist 1876 (EKLA, f 43, m 24: 37, l 1). Alahinnata ei saa isiklikke kontaktegi. F. Matson, kes oli Saaremaalt pärit, on kohtunud 1876. a suvel Kudjape kalmistul Hurdaga, sealt koos temaga Kuressaarde läinud ja tee peal mõnda sõna Eesti keele kirjapõhjast jutustanud. Kohtumine mehega, kes nii isalikult ja vennalikult oma Eesti rahva kasu nõuab, innustas kindlasti kogumistööle esimene saadetis koos eelosundatud kaaskirjaga 26. veebruarist 1877 (H I 4, 37) jõudis J. Hurdale järgmise aasta veebruaris.

Alates 1876. aastast intensiivistus rahvaluule kogumine tunduvalt - kogujaid oli rohkem ja kogumistöö haaras poole rohkem kihelkondi, kogujate ring uuenes (mõistatuste saatjate osas täielikult), rahvalaule koguti üle nelja korra rohkem, jutte saja võrra rohkem. Lühivorme, sealhulgas mõistatusi, laekus aga hoopis vähem kui eelneval perioodil. See on seletatav eelkõige rõhuasetusega lauludele ja Vana Kandle ilmumahakkamisega, mis näitas kogujatele nende töö väljundit.

Kõige intensiivsem oli kogumistöö aastatel 1876-1879, järgmisest aastast hakkas see vaibuma, mõistatuste osas lakkas täielikult. Seltsi koosolekul 20. jaanuaril 1881 ollakse sunnitud tunnistama, et 
[---] t a g a s i aga olla jäänud tegevus Vana vara korjamises: selles tähtjas ja hädalises töös, sest et hallikad pea võida ära kuivada, olla ergemat tegevust tarvis (EKmSi protokollid 1881a: lisa 3).

\subsection{Mõistatuste kogujad ja saadetised}

EKmSi üks produktiivsemaid kogujaid oli Räpina kihelkonna Kõnnu küla Miku talu vanapoisist ${ }^{3}$ peremees Jakob Jagomann (Põldmäe 1957: 65-72), kelle olid kogumistööle suunanud Jakob Hurda lellepoeg Johann Hurt ja Mihkel Veske. Seltsi kogujate hulgas suurima laulude korjandusega (655 laulu) silma paistnud J. Jagomann on saatnud ka 189 mõistatust.

Oma mõistatuste korjandusest kirjutab J. Jagomann J. Hurdale 8. mail 1877:

Ja om ka veel 200 mõistatust korjatu. Nee töö [mõtleb kogu rahvaluulekogumist - R. S.] ole mina siiamaale kiik ütsinda tennü ja oles sedä edespäidi ka tennü, kui minol oma tervüs käen oles olnu.

Edasi saame J. Jagomanni kirjast teada, mis teda ei luba praegu kogumistööd jätkata, nimelt sattus ta teeröövlide ehk mõrtsukate kätte:

Ja üts mõrtsuk lei minulõ 31/2-naklalise kiviga hää silmä ja silmäkolmu luu katski. [---] Ja siiamaale om mino pää ninda segane, et mina midage ei tiia, mes mina ole, kas eläv vai koolu (EKLA, f 43, m 6: 7, 1 2).

EKmSi saabunud kogu kannab tiitellehte Mõistatuse Ramad. 1875. aastal. Rahva suust kokko korjado. Kirjotedu Kõnnu külän Räppinä vallan Jakob Jagomann. 1877 (EKS 8 ${ }^{\circ}$ 5, 381). ${ }^{4}$ J. Jagomanni kirja põhjal 30. maist 1977 J. Hurdale on alust arvata, et J. Jagomann oma kirjapanekud ise Tartusse kohale tõi:

Kui Kirjameeste Selts soovip, siis või mina nee korjatu laulu ja vana jutu ja vana mõistatuse juunikuust kiik Tartohe viia (EKLA, f 43, $\mathrm{m}$ 6: 7). 


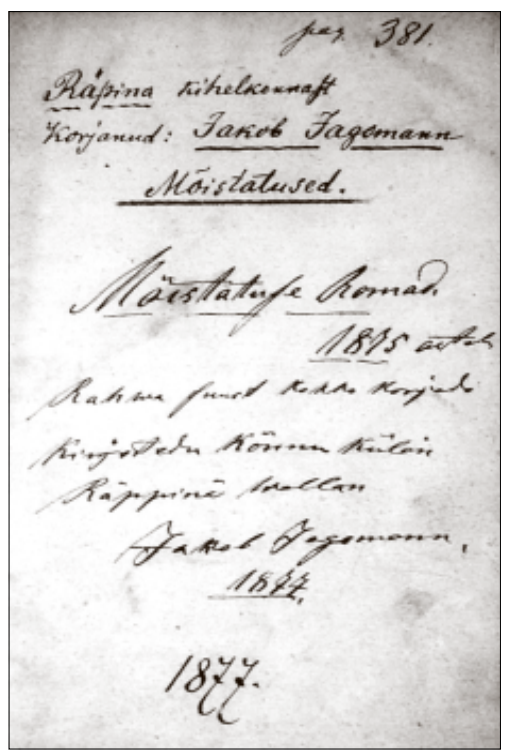

Foto 7. Jakob Jagomanni mõistatuste korjanduse tiitelleht. 1875-1877 (EKS $\left.8^{\circ} 5,381\right)$.

J. Hurt andis seltsi koosolekul 14. juunil 1877 aru laekunud vanavarast, protokollis on see sõnastatud nõnda:

J. Jagomann oli suure hulga laulusid, juttusid ja mõistatusi korjanud, mis ta seltsile ära müüs. Hind, mis nende eest makseti, ei arvatud ammugi mitte korjamise ja kirjutamise vaeva tasuda võivat, vaid arvati agarale korjajale üksnes väikeseks toeks olevat (EKmSi protokollid 1877b: 79).

Vähese hariduse tôttu on J. Jagomanni üleskirjutused ortograafia ja murdekeele poolest ebakindlad, vanast kirjaviisist mõjustatud, tema käekiri on väga raskesti loetav. Toome mõne näite J. Jagomanni kirjutusviisist:

Härk Mürra Muuru siissen Pikah. Puuh Pedäjak. Keriko keel (EKS $8^{\circ}$ 5, 406 (67); EM $298 \mathrm{Cb}_{1}$ );

Kaher istus kengo pääl kulatse känga jalah. Ader nurme pääl (EKS 8 5, 399 (21); EM $566 \mathrm{~A}_{2} \mathrm{~b}$ );

Siist sõitva siidi sagsa siist siidi kuninga, antva suud sulasile kat noorile mehile. Kui Inemise maggase peeru laskmine (EKS $8^{\circ}$ 5, 413 (96); EM $1966 \mathrm{~A}_{1} \mathrm{a}_{2}$ ).

Mõistatuste akadeemilise väljaandega töötamise käigus on peaaegu kõik kartoteeki kopeeritud J. Jagomanni tekstid tulnud üle kollatsioneerida, mõnikord toeks kahe J. Jagomanni käsikirja olemasolu (vt ka lk 185) ja tüübi ülejäänud variandid. Viimased on mõnelgi puhul hädast välja aidanud, nt EM 1966 Bb, kus teksti Siist sõidva siidi sagsa vasta vodi [või vadi - originaalis selgusetu, kas kirjutatud $a$ või o] kuninga... väljalugemisel oli toeks sealtsamast Räpina kihel- 
Rein Saukas

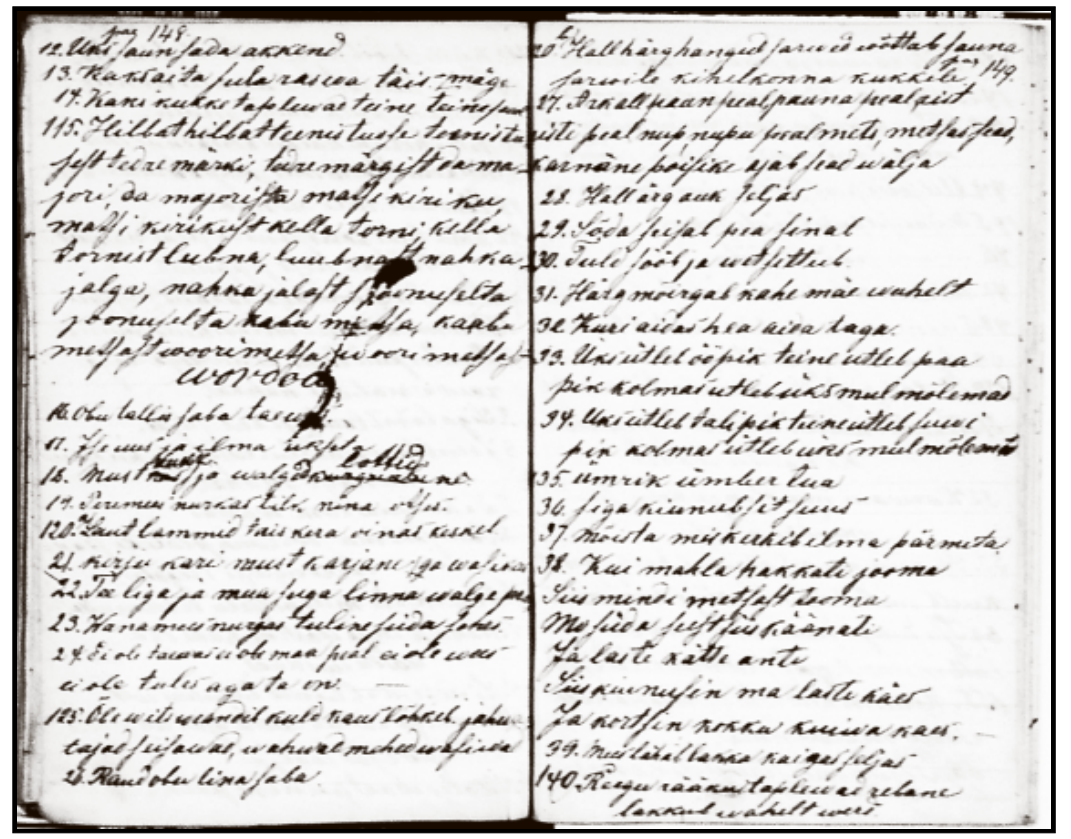

Foto 8. Karl Moksi mõistatuste üleskirjutus. 1878 (H, R 7, 148-149).

konnast Richard Viidalepa 1933. aastal üles kirjutatud Siit sõit siidisäks, vasta vaadi kuningas... (ERA II 63, 575 (38).

Samas on J. Jagomanni kirjapandud mõistatused autentsed, kajastavad kohalikku traditsiooni, ka väga lokaalset, nt:

Kuu näge, päiv varast, ago armast, võtme varast? Kaste (EM 4); Neiokese noorekese, sõsarekese sirgekese, tulep edimene manu, rõomurõivin, iluehten, sinitside siidega, verevide veerdega, kullakrooni preetsike? Agu ja päiva tõsemine (EM 128);

Hämm puu rajotas, kuiva' lastu' kargase? Kella löömine (EM 286, ainult Räpina khk);

Must voode, valge magaja? Pirru parsil (EM 1225);

Mõista ära, mis mõmmevitsa, kui ne pikä koovivitsa, pika puu ja hõrentusvitsa? Laodi (EM 1333).

Akadeemiline väljaanne Eesti mõistatused (EM) sisaldab ka seitse ainult J. Jagomanni üleskirjutusega esindatud tüüpi, nt: 


\section{Rein Saukas}

Naise kübär pääh, mehe vöö vööl? Hainakuhi (EM 1398);

Nõsta jõvvat, vissada ei jõvva? Sulg (EM 2304);

Ü̈̈müts pääh, savirõiva säljah? Ritsik ahju sees (EM 2616);

Üts ader kolme haeraga? Hainavikel (EM 2746).

Nagu tollele ajale omane, ei ole mõistatuste kogu juures andmeid selle kohta, kellelt materjal üles tähendatud on. Küll on aga teada, et J. Jagomann kirjutas laule üles teistestki Räpina kihelkonna paikadest peale oma koduküla. Võib arvata, et nii on ka mõistatused erinevatelt inimestelt, lisaks J. Jagomanni oma teadmus.

Teine suurem mõistatuste korjandus pärineb Karl Moksilt, kelle isiku kohta täpsemad andmed puuduvad. Teada on, et haritud mehena tegi ta kaastööd ajalehtedele Olevik, Oma Maa ja Postimees, tema sulest ilmus raamatuid (Annus 1995: 3117-3120). Rahvaluulekorjanduse saatis ta seltsile 1878. a ja see moodustab tervikliku köite H, R 7, kus 220 mõistatust on lehekülgedel 141-157 ja nende lahendused lehekülgedel 164-169. Mitmel korral kirja pandud mõistatused kinnitavad korjanduse pidevat täiendamist, kasutatud on erinevaid sulgi ja tinte, nr 213-220 on hoopis pliiatsikirjas. Huvitav on märkida, et üks mõistatus (nr 155) on vene ja kolm (nr 157-159) saksa keeles. Kirjapanekud on kirjakeeles, üksikute murdeelementidega. K. Moksi mõistatuste kogu on üldjoontes autentne, esindades valdavalt suuri tüüpe, üksikuid näiteid on ka lokaalsest traditsioonist:

\footnotetext{
Hilbat-hilbat teenistusse, teenistusest tedremärki, tedremärgist damajori, damajorista matsi kiriku, matsi kirikust kellatorni, kellatornist luubna, luubnast nahkajalga, nahkajalast joonusele, joonuselta kaabumetsa, kaabumetsast voorimetsa, voorimetsast vordou? Inimese söögi käik (EM 224);

Ise puu ja Mikk nimi? Südamik (EM 411);

Vana oinas, uhtsaba, vana lammas, laimagu? Luud ja labidas (EM 2407).
}

Kuid ühena vähestest EKmSi mõistatuste kogujatest on K. Moks kasutanud trükist, nimelt nr 170-187 ja 206-209 lähtuvad C. E. Mötleja Mõistatuste raamatust (1878).

Suuremad mõistatuste korjandused on veel Jõelähtme kihelkonna Ülgase koolmeistrilt F. Matsonilt ja mõisa toapoisilt (teenrilt) Jüri Reinsonilt Pärnu-Jaagupi kihelkonnast.

Mõistatuste (kokku 516) kogumisest EKmSis Jakob Hurda juhendamisel aastatel 1876-1881 annab ülevaate ka tabel lk 186-188. 


\section{Mõistatuste kogumine Eesti Kirjameeste Seltsis aastatel 1882-1893}

\subsection{Kogumistööst üldiselt}

Jakob Hurt lahkus EKmSi presidendi kohaltja seltsist endast 1881. a augustis. Uueks presidendiks sai Carl Robert Jakobson (1841-1882), kelle tegevusvaldkond hõlmas ka rahvaluulekogumist. Oma esimeses presidendina peetud kõnes pidas ta rahvaluule kogumist ja publitseerimist seltsi üheks oluliseks töölõiguks:

Aga meie peame seda kulda ka edasi korjama, kus teda veel vana varemete ja prü̈̈gide vahelt leida on, et ta mitte jäedavalt kautsi ei jäeks ja uues kujus rahva seas jälle käima võiks hakata (Eesti Kirjameeste Seltsi aastaraamat 1881 lisa: 31).

Kahjuks ei lubanud varane surm 1882. a märtsis C. R. Jakobsonil sellel tööpõllul midagi silmapaistvat korda saata.

Aastatel 1882-1886 juhtis seltsi ja rahvaluulekogumist Mihkel Veske (1843-1890), kes püüdis J. Hurda ajal aktiivselt tegutsenud, kuid selleks ajaks lagunenud kogujate võrku taas ellu kutsuda, paraku küll üsna edutult. Aastaraamatute, käsikirjaliste protokollide ja muude arhiivimaterjalide põhjal on teada 25 kaastöölist, ka käis M. Veske ise kolmel korral Virumaal kogumismatkal. Säilinud ülestähendatud materjalides pole mõistatusi ja üldse on peaaegu terve Virumaa materjal kaduma läinud, nagu suurem osa M. Veske kätte kogunenud muudestki rahvaluulekirjapanekutest.

1886. a sügisel siirdus M. Veske õppejõuks Kaasani ülikooli, seltsis hakkas rahvaluule-

Foto 9. Jaan Jõgever, kogumistöö juht aastatel 1886-1893. R. Borchardti foto 1870.-1880. aastatest. Riia (EKLA, A 37: 5932).

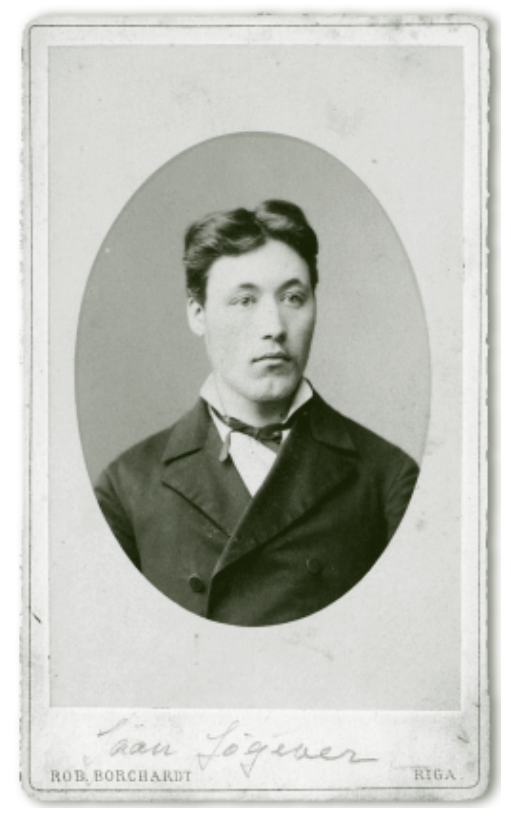




\section{Rein Saukas}

küsimustega tegelema Juhan Kunder (1852-1888), peamiselt aga Jaan Jõgever (1861-1924). J. Jõgever sai samal aastal Oma Maa tegevtoimetajaks ja avaldas juba selle esimeses numbris (aprillis) mahuka kava rahvaluule kogumiseks "Hea nõu kooliõpetajatele, kooliõppijatele ja igale teaduse sõbrale". Ta püstitab ülesande koguda, sest

[---] meie piame ruttama veel seda, mis olemas on, paberi peale ülesse võtta, kust ta enam kaduma ei lähe, seisku ta küll kas aastakümnete kaupa käsikirjades, [---] kust õpetatud mees teda tavalisel korral leiab (Jõgever 1886: 22).

Oma kogumispalve suunab J. Jõgever koolmeistritele, kuna

[---] põllumehel ei ole aega kirjutada, tema piab enese ja oma koolitatud abiliste ülespidamise eest muret kandma, sellepärast ei julge mina ka teda selle väljale kutsudagi (Jõgever 1886: 23).

Kava esimese jaotuse "rahva kirjandus" viies alajaotus on "mõistatused ja nende kostused" (esmakordselt on siin nimetatud ka lahendusi). Täpsemaid kogumisjuhiseid J. Jõgever ei andnud.

Samal aastal asub kogumistööd õhutama ka Juhan Kunder, kes peab 17. juunil seltsis kõne "Mõnda Eesti rahva luuletustest" (Kunder 1886), milles esitatud kogumiskava 9 punktist kaks puudutavad mõistatusi:

4) Mõistatused ja vanad sõnad. [---] 7) Rahva rehkendus. Näituseks: Ühes veskis neli kotti, igal kottil neli soppi, igas sopis neli kassi; igal kassil neli jalga, mitu kassijalga kottis (Kunder 1886: 231).

Näite toomine oli tolleaegsetes kogumiskavades-üleskutsetes üsna haruldane.

J. Kunder juhtis tähelepanu ka mitmele organisatoorsele momendile. Seltsis peaks korrespondentidega kirjavahetuse teel tegelema seltsi poolt määratud isik:

Sest ilma väsimata kirja-vahetuseta ei tule jällegi sellest asjast midagi välja. Kõik rahva luuletuste korjajad annavad selle seltsist nimetatud mehele omad nimed ülesse ja võtavad omas 
Rein Saukas

ümberkaudses oma arvamise järele korjajaid abiks (Kunder 1886: 231).

Aruandeid esitatakse seltsi suurkoosolekutel kaks korda aastas, misjärel need avaldatakse ajakirjanduses. Parematele kogujatele tuleks nende töö eest rahalist tasu maksta ehk J. Kunderi sõnastuses:

Kui võimalik, saagu hoolsaste korjajatele auupalkasi lubatud ja välja antud (Kunder 1886: 231).

Oma ettekande lõpetas J. Kunder:

See töö on küll seda väärt, et meie kõige jõuuga tema kallale läheme [---] (Kunder 1886: 231).

Seltsi koosolekutel oli teisigi, kes rahvaluule kogumise tähtsust rõhutasid, nt lausub Jakob Martin Sommer oma ettekande "Viru Eestlaste endistest pulma pruukidest" lõpus:

Vanavara korjamine on väga tarviline ettevõtmine praegusel ajal, kui see ülikallis varandus mitte kautsi ei pia minema. Sellest ôpime meie vast tundma, missugused meie esivanemad olnud ja kuidas nad avalikuil asja tallitustel oma mõtteid on avaldanud. [---] Ja niisugust vaimu vara on veel paiguti küllalt leida, mida meie sõeluma ja kokku koguma piame, kui meie tõsise meelega Eestlased tahame olla ja oma esivanemate haudasid auustada. Piaks need sõnad mõnda kuuljat sellele auusale tööle äratama, siis oleks minu soojem soov vanavara korjamise kasu kohta täidetud! (Sommer 1883: 77).

Paraku lahkus ka J. Kunder ${ }^{5}$ kodumaalt ja nii jäi seltsis rahvaluulekogumist juhendama ja publitseerimisküsimustega tegelema Jaan Jõgever ainuisikuliselt. Eesmärgiks seadis ta publitseerimise sarjas "Eesti Muinasaeg". J. Jõgeveril polnud niisuguseid organisaatorivõimeid kui J. Hurdal, pealegi tegi ta seda tööd rohkem oma huvides, nagu võime järeldada tema kirjast J. Hurdale 1. novembrist 1893 (EKLA, f 43, m 6: 38, 1 1-2). Kogumistöö virgutamisel hakkas olulist rolli mängima ajakiri Oma Maa, mille tegevtoimetaja oli aastatel 1886-1891 J. Jõgever ise. Mitmed kogujad saatsid oma materjali otse ajakirja toimetusse (mõistatusi nt J. Hannus, Joosep Melzov, ${ }^{6}$ Villem Mägi). P. Nõggese saadetud 12 mõistatust polegi käsikirjas 


\section{Rein Saukas}

meieni jõudnud, küll aga ilmunud ajakirjas $\operatorname{Oma} M a a$ 1886, nr 6 märkusega "Rahvasuust". Ajakirjas avaldatud mõistatuste saatja isikuni aitab jõuda P. Nõggese kiri, mis Oma Maa toimetuse arhiivis säilinud:

Siin saadan teile ühe vanaaegse jutukese ja tosina mõistatusi (EKLA, f 51, m 36: 1, 1 200-201). ${ }^{7}$

Ilmselt käsikirja puudumise tõttu pole V. Mälk P. Nõggese materjali EKmSi kogumistöösse arvestanud.

Võrreldes eelneva aastakümnega oli kogumistöö juhendamine tagasihoidlik ja vastavalt sellele ka tulemused - saak mahub lahedasti säilikutesse EKS $4^{\circ}$ 5; H, Jõgever 2; H, Jõgever 3. Kogunenud materjali saatis Jaan Jõgever pärast EKmSi sulgemist 1893. a J. Hurdale. Aruandes (Hurt 1893) ei maininud J. Hurt saatja soovi kohaselt seltsi, vaid kirjutas J. Jõgeverist, kes oli talle läkitanud 45 postpoognat ja 188 kirjutuspoognat kõigesugust vanavara materjaali. Nii sai kõik EKmSi egiidi all kogutud vanavara ühte kohta kokku, moodustades kogu šifritega EKS $4^{\circ}, 1-5$ ja $8^{\circ}, 1-5$. Esimesel perioodil kogutud materjalid on komplekteeritud üheksasse köitesse, teise perioodi materjal ühte köitesse. Paberi formaadilt erinevad saadetised on J. Hurt paigutanud enamasti oma põhikogu köidetesse H I 4; H, R 3, 6 ja 7; H, Jagomann; H, Kolga-Jaani 2-3, vähesel määral ka seeriatesse II, III ja IV. Teisel perioodil kogutud rahvaluulet leidub ka säilikutes H, Jõgever 2-3.

\subsection{Mõistatuste kogujad ja saadetised}

Mõistatusi saatsid Jaan Jõgeverile kaheksa kogujat - J. Hannus, Jaan Truusmann, Villem Mägi, Aleksander Wahlbergi pärijad, T. Kiimann, A. Madisson, J. Melzov, P. Nõgges.

A. Wahlbergile kuulub selle perioodi kõige suurem mõistatuste kogu, mille sugulased pärast tema surma 1888. a EKmSi läkitasid, teadmata, et lahkunu oli sama materjali juba 1874. a seltsile saatnud ja kõnesoleva 143-leheküljelise saadetise näol oli tegemist mustandkäsikirjaga. Mõistatused on käsikirjas esitatud kahes numeratsioonis: 1-284 alfabeedis, uus osa 1-33 juhuslikus järjekorras. Siinkohal võiks lisada sedagi, et 1940. a jõudis Nõo algkooli juhataja Edur Tasa vahendusel Eesti Rahvaluule Arhiivi kolmaski A. Wahlbergi käsikiri (ERA II 198, 400-406, 458-459 (mõistatusi sisaldavad lehe- 


\section{Rein Saukas}

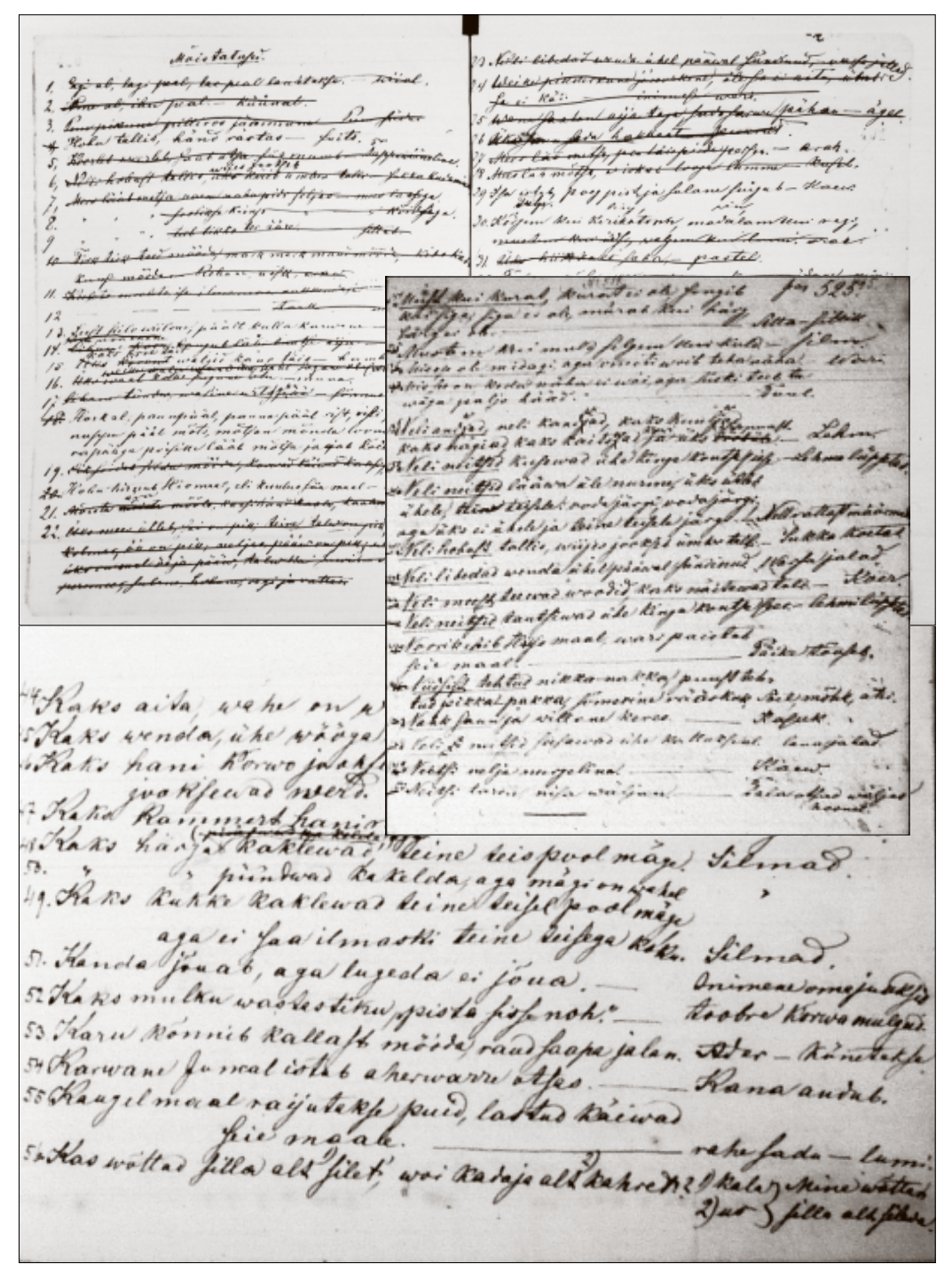

Foto 10. Aleksander Wahlbergi mõistatuste käsikirju on ERAs kolm, üks esinduslik puhtand ja kaks mustandit, mis jõudsid arhiivi alles pärast koguja surma (EKS $4^{\circ}$ 3, 347; EKS $4^{\circ}$ 5, 525; ERA II 198, 400-401). 


\section{Rein Saukas}

küljed)). Viimane on ilmselt tema kõige algsem mustandkäsikiri, milles mõistatused ei ole alfabeedis, enamikule on kriips peale tõmmatud, mõnele leheküljele $(402,404)$ on serva peale kirjutatud nimesid: Ado Sild, Peeter Hiop, Rostenbock - kas need on isikud, kellelt mõistatusi on üles kirjutatud, või nn kaaskorjajad, kes kogutu A. Wahlbergi kätte toimetasid, ei ole arusaadav. Mõlemas mustandkäsikirjas on üksikuid niisuguseid tekste, mida A. Wahlberg puhtandkäsikirja ei kirjutanud.

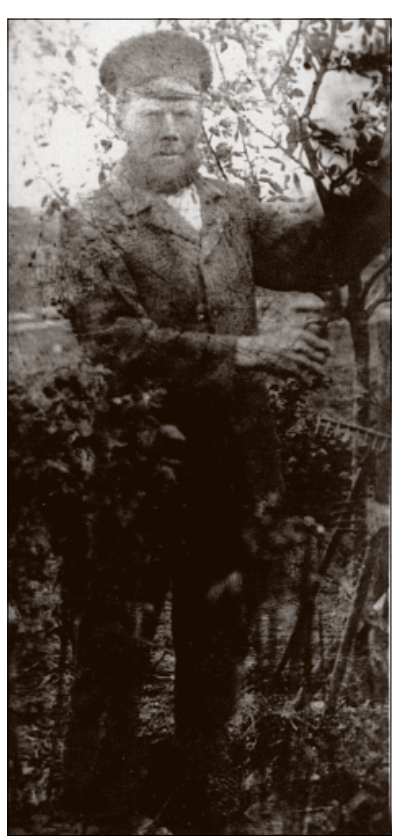

Foto 11. Villem Mägi (ERA 119).

Kõige aktiivsem koguja kokku kümne saadetisega oli Villem Mägi, Karja kihelkonna Aru valla kultuurihuviline vabadik, kellel oli rohkem kui 200 raamatust koosnev raamatukogu, kes tellis kaheksat ajalehte, oli Saarlase kirjasaatja, avaldades lehe veergudel kodukihelkonna uudiseid ja oma luuletusigi. Suviti on ta mandril tööl käinud (Mälk 1963: 243245).

See kõik pole jätnud mõjutamata ka tema mõistatuste kirjapanekuid. Igatahes ei esinda V. Mägi kirjapanekud ehtsaaremaalisi mõistatustüüpe, kuigi ka neid leidub, nt Oherdi upub kiske väina? Naba (EM 1493); Riksub-raksub rikka mehe värava taga? Tuuleveski (EM $1847 \mathrm{Ba}$ ), nagu ka suuremate tüüpide Saaremaaredaktsioone, nt Kaks penni valged kanu täis? Hambad suus (EM $533 \mathrm{~A}_{4}$ b); Puhkam-muhkam tuli uksest sise, puhus mulla, leidis kulla, pistis seinaprau vahele? Siga leiab viljatera, sööb ära (EM 2224); Tuhat-tuhat, sada-sada, ühe ööga, kahe otsaga? Õlevihk, kubu (EM $2279 \mathrm{Za}_{1}$ ). Materjalis leidub erandlikke tekste, mis oleks nagu "seatud", nt Lõhub majad, lõhub metsad, siiski ei ole kellegil näha? Tuul (EM 97 F+); Kasvab ja kahaneb, siski ei sure? Kuu; Mis kasvab ja kahaneb, siiski ei lähe suuremaks ega jäe vähemaks? Kuu (EM $\left.598 \mathrm{~B}^{+}\right)^{8}$

Omaette probleem on V. Mägi mõistatuste geograafilise päritolu kindlakstegemisega. Oma dateerimata mõistatusteseeria lõppu kirjutab ta: 
Need mõistatused olen mina Mustjala ja Karja rahva seas kokku korjanud - sellepärast ei ole nemad mitte üksnes Karja, vaid ka Mustjala rahva omad (H, Jõgever 2, 165).

Tavaliselt on mõistatusesaadetiste geograafiline päritolu aga hoopis määratlemata, muu materjali puhul tulevad kõne alla peaaegu kõik Saaremaa kihelkonnad. Mõistatuste akadeemilises väljaandes on V. Mägi mõistatuste päritolukohaks arvestatud Saaremaa.

Kolmanda selle perioodi suurima mõistatuste koguja T. Kiimanni saadetis seevastu on rahvaehtne, küll kirjakeelne, aga siiski mõningate murdeelementidega. Tüüpi Tuhat tutikast, sada satikast? Õunapuuõied (EM 2268) esindabki ainult T. Kiimanni üleskirjutus.

Mõistatuste (kokku 696) kogumise kohta Jaan Jõgeveri organiseerimisel annab ülevaate ka tabel lk 186-188.

\section{3. Ühte-teist mõistatuste kogumise asjaoludest}

Mõistatuste kogumise kohta leidub arhiivis väga vähe kogujapoolseid andmeid.

Kellelt või kuidas mõistatusi kirja on pandud, sellest saab natuke aimu kirjadest ja notiitsidest saadetiste juures. On selge, et Muhu talupoeg O. T. K. kirjutab omaenda teadmust, J. Jagomann on tõenäoliselt mõistatusi üles tähendanud mitmest kohast ja mitmelt isikult. Et A. Wahlberg lisaks oma teadmusele ka mujalt andmeid on kogunud, näitab lõik tema kirjast Hurdale 28. märtsist 1876:

Siiski olen silmad lahti ja kõrvad erku hoidnud ja kui väha ruumi, paberisse pistnud, mis väha vana värvi näites. [---] Vanad sõnad ja vanad riismed, mis ma Teie kätte läkitasin, lasksin ma kõigist oma kihelkonna ametivendadest läbi käia, et igaüks senna pidi oma täädused juure panema, aga sest ei tulnud midagi välja. Üks es kuule, tõne es näe, kolmas oli koguni jume (EKLA, f 43, m 24: 37, l 1).

P. Nõgges Rannust tunnistab, et ta mõistatused küll rahvasuust üles kirjutanud, aga ei ole, nagu nähtub tema 1886. aasta 20. juuliga dateeritud kirjast Oma Maa toimetusele (EKLA, f 51, m 36: 1, 1 200-201), seejuures päris kindel, kas mõned neist juba kusagil trükitud ei ole. 
Rein Saukas

F. Matson ja C. Allas mõlemad on organiseerinud enda ümber väikese kogujate ringi. Kooliõpetaja F. Matson kirjeldab kirjas Jakob Hurdale 10. oktoobril 1878 oma kogumistööd nii:

Korjamine sündis järgmisel viisil: esiteks ostsin ma 4 raamatud paberid ja jägasin seda minu ametivendadele ära, nõnda kuida igaüks arvas oma poolt korjamiseks paberid tarvis olevad. Minu abilised olivad Johannes Jacomberg Kostiverest, Johannes Reimtag Jägalast, Karl Mühlbach Rummust. Nemad jägasivad seda paberid oma koolilaste kätte välja. Kui juba mõned poognad täis olivad, siis saatsivad minu kätte. Aga mis ma leidsin!? Mõned olivad nii sandeste kirjutanud, et suure arvamisega aru võis saada ja muist jäivad hoopis mõistmataks. Palju olivad ühest ja teisest koolist ühesugusi juttusi kirjutud. Mõned jälle niisugusi, mis ma juba ammu arvasin presidendi käes olevad. Teised jälle hoopis niisugusi, mis kohugi ei kõlba. Nüüd ei jäänud muud nõu üle, kui et pidin kõik need poognad uueste ümber kirjutama (H I 4, 123).

Samamoodi on C. Allas jaganud paberit ja kirja materjali neile, keda ta kogujaks oli suutnud värvata, selgub tema kirjast J. Hurdale 11. septembril 1872 (H, R 4, 13-14). Vahemärkusena olgu öeldud, et niisugune kogumismeetod on vähemalt lühivormide puhul üks halvemaid. Need üksused, mis kogumistöö organiseerija kätte jõuavad, võivad olla pärit ka kirjandusest. Kui see laekunud materjal nüüd omakorda ümber korraldatakse, näiteks alfabeeti pannakse, siis osutub tekstide rahvaehtsuse selgitamine üsna keeruliseks, kui mitte hoopis võimatuks. Nii on A. Wahlbergi muidu autentses, aga alfabeeti pandud mõistatuste saadetises niisuguseid tekste, mis saavad lähtuda ainult O. R. Holtzi raamatust Luggemissed Eestima Tallorahva Moistusse ja Süddame Juhhatamiseks (Tallinn 1817). Analoogsed on ka osa mitme hilisema aja kooliõpetajate (M. Mäesalu, M. Patte) saadetistest, mis kujutavad endast valikut väga paljude oppilaste kirjapanekutest.

C. Allase notiitsidest saame aimu ka juba küsitlemisest endast. Laulikuid ja jutustajaid on ta pidanud, nagu selgub kirjast 11. septembril 1872, 1000-aastaseks kalendriks ja suureks saladuse salgaks ning tagavara aidaks, kellele ta esmalt püüdis vanu sõnu ja laulusid tulusad ja kasulikud välja näita $(\mathrm{H}, \mathrm{R} 4,13)$, imestades, et vanad inimesed niisuguseid asju teavad, millest noorematel aimugi pole. Samast kirjast loeme: 
Mitu kord soiguvad, et ää puhas kääst ununud, aga kui seda mõne vana jutuga äratada, tõusvad maast üles, nagu üks pea 80 a [astane] taat ütles naerdes: see teeb ette mind veel üsna nooreks, kisub keele köidiku kõlisema (H, R 4,13).

Selline lähenemine oma informandile on hiljem saanud üheks kogumistöö põhitõeks.

Peamise kogumistööd takistava asjaoluna on nimetatud seda, et aega ei ole piisavalt. A. Wahlberg kirjutas 28. märtsil 1876. aastal J. Hurdale:

[---] mitmed takistused on keeluks olnud, nimelt põllutöö suvel ja kooliamet talvel on aega palju käest ära kiskunud ja igal pool sammude sidujaks olnud vana vara korjates (EKLA, f 43, m 24: 37, l1p).

Ülimalt huvitav on F. Matsoni rehkendus selle kohta, kui palju tal on kulunud aega ühe konkreetse saadetisega (72 laulu, 30 juttu, 40 mõistatust). F. Matsoni kirjast 10. oktoobril 1878 loeme:

[---] oma aega selle tarbis olen ma pidanud pruukima 2. jaanuarist kuni 30. märtsini 2 tundi päävas. Kui pühapäävad maha arvame, siis on 72 pääva, see teeb 144 tundi ehk 6 pääva. Nõnda oleks siis 6 pääva ööd ja päävad kirjutatud saanud, kus iga tunni peale $1^{2} /{ }_{7}$ poognat kirjutada oleks (H I 4, 124).

Rahvaluulekogumise algaastatel valmistasid kohalikele korrespondentidele peavalu variandid. Kehtinud arusaamine oli niisugune: kui juba üks variant on kirja pandud, siis rohkem poleks nagu vajagi. Ehk koguja sõnadega eelosundatud kirjast:

Võib olla, et mõni just niisama pikad keeled saatnud, mis niisama jämedad ja nõndasama helisevad - siis on kõik minu töö üks tühi aja närimine (H I 4, 123).

\section{Rahvaluule publitseerimise kavadest Eesti Kirjameeste Seltsis}

Kaheksandal koosolekul 26. ja 27. septembril 1875 esitab J. Hurt seltsile kava, kudas korjatud vana vara trüki läbi välja anda tuleks: 1) vana kannel (laulud), 2) vana tarkus (vanad-mõistusõnad), 3) vana 


\section{Rein Saukas}

usk, 4) vanad jutud, 5) vanad kombed (pulmade, ristmiste, matmiste, talguste juures), 6) rahva lauluviisid (EKmSi protokollid 1875b: 101).

Nagu näeme, ei ole siin mõistatusi nimetatud.

Nagu eespool juba vihjatud, kavandas J. Jõgever oma kogumisaktsiooni tulemusel laekuva materjali kohest ja järjekindlat publitseerimist (M. J. Eisen tegutseski kogu aeg just sel põhimõttel). Seltsi koosolekul 1887. a ette kantud rahvaluule publitseerimise kava "Eesti Muinasaeg" jaotus "I liik: Kirjandusline vanavara" sisaldas omakorda alajaotuse "4. jagu: Mõistatused ja vanad sõnad”. J. Jõgeveril õnnestus avaldada seltsi aastaraamatu lisana kimbukene jutte, mõistatusteni ta aga ei jõudnud. Samal 1887. a asus väljaandmise eesmärgiga jõuliselt mõistatusi koguma Matthias Johann Eisen.

\section{Eesti Kirjameeste Seltsi liikmete Mihkel Veske ja Carl Robert Jakobsoni tegevus rahvaluule kogumisel 1870. aastatel}

Rahvaluule kogumist Eesti Kirjameeste Seltsi abiesimehe ja aastaraamatu toimetaja Mihkel Veske poolt ja sellealast tagasihoidlikku organiseerimistööd (tal olid isegi mõned kaastöölised) 1870. aastatel on põhjust vaadelda eraldi. M. Veske tegutses üsna iseseisvalt, jäi nagu üldisest kogumistööst kõrvale ja tema materjalidki ei ole liidetud seltsi kogusse. Kuid samas sai ta siiski 1878. ja 1879. a seltsilt kogumismatkadeks rahalist toetust, esines seltsi koosolekutel aruannetega oma kogumistööst ja ettekannetega eesti rahvaluule probleemidest. M. Veske põhitähelepanu oli suunatud rahvalauludele kogumismatkadel käis ta Viljandi-, Viru-, Võru- ja Setumaal. Ta avastas ka ühe oma aja suurlauliku Epp Vasara Paistu kihelkonnast. Kahjuks oli M. Veske äärmiselt hoolimatu kirjapandu vormistamisel ja säilitamisel, vastupidiselt näiteks äärmiselt korrektsele Jakob Hurdale. Suur osa tema materjalidest on kadunud või säilinud pelgalt Kaarle Krohni koopiatena. ${ }^{9}$

Mõistatuste teema ja M. Veskega seoses tuleks siinkohal nimetada eelkõige kahte korjandust, kuigi M. Veske rahvaluulekogus leidub vähesel määral teisigi geograafiliselt määratlemata ja dateerimata anonüümseid kirjapanekuid.

Nimelt on Mihkel Veske Õpetatud Eesti Seltsi koosolekul 18. jaanuaril 1875. a esitatud ettekandes laulik Epp Vasarast kõnelnud, kuidas viimane eelmise aasta 12 . detsembril talle 70 mõistatust kii- 
resti üksteise järel dikteeris, päeva pärast veel 30 ja hiljem 20 , seega kokku 120 mõistatust (Sitzungsberichte der Gelehrten Estnischen Gesellschaft zu Dorpat 1875. 1876: 21). Kirjameeste Seltsi koosolekul 26. ja 27. septembril 1875 rääkis M. Veske samuti Epp Vasarast, kes temale umbes 700 laulu olla laulnud, mõistatustest ta aga seekord juttu ei teinud (EKmSi protokollid 1875b: 101). On tõeliselt kahju, et suurlauliku mõistatuste repertuaar (või osa sellest) ei ole M. Veske lohakuse tõttu meieni säilinud, seda enam, et varasest kogumisperioodist pole nimeliselt teada ühtegi teist mõistatuste esitajat ega esitamise kirjeldust.

1875. a kogumismatkal Võrumaale on M. Veske ilmselt kohtunud ka meile juba tuttava Jakob Jagomanniga, kes 26. novembril 1875 kirjutab M. Veskele, et minul on hä̈̈ summa vanaaegsid mõistatuisi korjatu, kui teie soovite, siis võin mina teile ära saata, lubab enne jõule Tartusse minna ja seal M. Veskega kokku saada (EKLA, f 149, m 5: 9, 1 1). Tõenäoliselt on kavatsetu teoks saanud, sest M. Veske kogus on käsikiri Möistatuse ramat. 1875. Kirjodetu Räppinal sel 20 Dez 1874. J. Jagomann (Veske 4, 435-468). Korjandus sisaldab 146 mõistatust, millest esimesed 130 esinevad ka EKmSile (J. Hurdale) saadetud mõistatustevihus, viimaseid numbreid (s.o 131146) aga selles korjanduses ei leidu.

Seltsi juhtiva tegelase Carl Robert Jakobsoni huvi rahvaluule vastu näitas juba tema soov saada sellealast näitematerjali oma kooliõpikute ilmestamiseks. Näiteks luuletajana tuntud Juhan Weitzenberg on 1866. a 9. detsembri kirjas C. R. Jakobsonile saatnud 122 mõistatust Kooli lugemise raamatus avaldamiseks (EKLA, f 47, $\mathrm{m} 48: 46,15-8$.). 1870. aastate esimesel poolel on J. Hurt oma kirjades palunud C. R. Jakobsoni teha selgitustööd vanade laulude korjamiseks. 1878. a ilmuma hakanud Sakalas asuski C. R. Jakobson rahvaluulekogumist tutvustama ja kogumistööle õhutama. Kuigi tagasihoidlikult, saatsid ometi 27 teadaolevat kogujat C. R. Jakobsonile rahvaluulelist materjali (Mälk 1963: 150-151), nende hulgas on ka üks mõistatuste koguja - Peet Käär Järva-Jaani kihelkonnast Selikülast. Mõistatused (kokku 27 punkti) leiduvad tema 18801881. a kirjades Jakobsonile (EKLA, f 47, $\mathrm{m}$ 23: 22). Viit neist saab pidada omaloomingulisteks tähemängudeks. Daatumita kirjas, millele C. R. Jakobson(?) on punase pliiatsiga kirjutanud "Kirjameeste Seltsile", leidub aga juba 21 mõistatust. ${ }^{10}$ Saateks mõistatustele kirjutab P. Käär: 


\section{Rein Saukas}

Siin saadan ma paar Eesti vanad mõistatust "Sakala" toimendajale selle sooviga: tehku nad, mis arvavad. Minu poolt on aga ütelda, et nad tänini veel kusagil trükitud minu silma pole puutunud. Raamatu pookijat ja kauplejat Ermi ${ }^{11}$ kes Mõistatuste raamatuid valmistas, aitasin vana mõistatuste korjamises, siis ei tulnud neid ette (EKLA, f 47, m 23: 22, 1 23).

\section{Kokkuvõtteks}

\begin{tabular}{|c|c|c|c|}
\hline Koguja & Aasta & $\begin{array}{l}\text { Mõistatuste } \\
\text { päritolukoht }\end{array}$ & Arv \\
\hline A. Janushoff & 1872 & Karja & 5 \\
\hline $\begin{array}{l}\text { Ida Kallas } \\
\text { (1875. aastast } \\
\text { Niggol, 1853-1929), } \\
\text { R. Kallase ode, Carl } \\
\text { Heinrich Niggoli } \\
\text { abikaasa }\end{array}$ & 1872 & Kaarma & 65 \\
\hline $\begin{array}{l}\text { O. T. K., } \\
\text { „talupojamees“ }\end{array}$ & 1872 & Muhu & 39 \\
\hline $\begin{array}{l}\text { G. Soo, } \\
\text { kihelkonnakooli } \\
\text { õpetaja, köster, } \\
\text { EKmSi liige }\end{array}$ & 1874 & Võnnu & 30 \\
\hline $\begin{array}{l}\text { Gustav Johannes } \\
\text { Treumann (1849- } \\
\text { 1918), kooliõpetaja, } \\
\text { vallakirjutaja, } \\
\text { pärastine } \\
\text { kaupmees, EKmSi } \\
\text { liige }\end{array}$ & $1874 ?$ & $\begin{array}{c}\text { Risti või Harju- } \\
\text { Madise }\end{array}$ & 73 \\
\hline T. Rohke & 1875 & Saaremaa & 34 \\
\hline $\begin{array}{l}\text { Johannes Kerg } \\
\text { (1849-1926), } \\
\text { teoloogiaüliõpilane, } \\
\text { pärastine } \\
\text { kirikuõpetaja, } \\
\text { EKmSi liige }\end{array}$ & 1875 & Nõo & 74 \\
\hline
\end{tabular}


Rein Saukas

\begin{tabular}{|c|c|c|c|}
\hline $\begin{array}{l}\text { Aleksander } \\
\text { Wahlberg (1839- } \\
\text { 1888), kooliõpetaja, } \\
\text { EKmSi liige }\end{array}$ & 1875 & Helme & 317 \\
\hline $\begin{array}{l}\text { Carl Allas (1838- } \\
\text { 1910), } \\
\text { kihelkonnakooli } \\
\text { ópetaja, köster, } \\
\text { R. ja I. Kallase onu }\end{array}$ & dateerimata & Kaarma, Karja & 28 \\
\hline $\begin{array}{l}\text { Rudolf Kallas } \\
\text { (1851-1913), } \\
\text { kooliõpetaja, } \\
\text { pärastine } \\
\text { kirikuõpetaja, } \\
\text { I. Kallase vend, } \\
\text { EKmSi liige }\end{array}$ & $\begin{array}{c}\text { dateerimata, enne } \\
1876\end{array}$ & Pöide?, Võrumaa? & 106 \\
\hline $\begin{array}{l}\text { Anon EKS } 4^{\circ} 4 \text {, } \\
392-395(2-33)\end{array}$ & $\begin{array}{c}\text { dateerimata, enne } \\
1876 \\
\end{array}$ & Saaremaa? & 31 \\
\hline $\begin{array}{l}\text { Anon EKS } 8^{\circ} 1 \text {, } \\
348-349\end{array}$ & $\begin{array}{c}\text { dateerimata, enne } \\
1876 \\
\end{array}$ & Saaremaa & 11 \\
\hline $\begin{array}{l}\text { Anon EKS } 4^{\circ} 4 \text {, } \\
431-438(1-66) \& H \text {, } \\
\text { R 5, 123-126 (67- } \\
114)\end{array}$ & $\begin{array}{c}\text { dateerimata, enne } \\
1876\end{array}$ & Teadmata & 114 \\
\hline $\begin{array}{l}\text { Jüri Reinson, mõisa } \\
\text { toapoiss, EKmSi } \\
\text { liige }\end{array}$ & 1876 & Pärnu-Jaagupi & 62 \\
\hline $\begin{array}{l}\text { Jakob Jagomann } \\
(1844-1910), \\
\text { põllumees }\end{array}$ & 1877 & Räpina & 189 \\
\hline $\begin{array}{l}\text { Frido Matson } \\
\text { (1854-?), } \\
\text { kooliõpetaja }\end{array}$ & 1878 & Jõelähtme & 40 \\
\hline $\begin{array}{l}\text { Karl Moks, } \\
\text { pärastine statistika }\end{array}$ & 1878 & Põltsamaa & 220 \\
\hline
\end{tabular}




\section{Rein Saukas}

\begin{tabular}{|l|c|c|c}
\hline $\begin{array}{l}\text { Joosep Melzov } \\
\text { (1857-1915), } \\
\text { kooliõpetaja, EKmSi } \\
\text { liige }\end{array}$ & 1886 & Põlva & 12 \\
\hline $\begin{array}{l}\text { P. Nõgges } \\
\text { Villem Mägi (1863- }\end{array}$ & $\begin{array}{l}\text { 1888, 1889, } \\
\text { 1919), vabadik, } \\
\text { aednik, juhutööline, } \\
\text { ajalehtede } \\
\text { kaastööline }\end{array}$ & $\begin{array}{c}\text { Saaremaa, Karja, } \\
\text { Karja või Mustjala }\end{array}$ & 12 \\
\hline $\begin{array}{l}\text { J. Hannus } \\
\text { Jaan Truusmann, } \\
\text { kooliõpetaja }\end{array}$ & 1886 & & 146 \\
\hline $\begin{array}{l}\text { Aleksander } \\
\text { Wahlbergi pärijad }\end{array}$ & 1888 & Võnnu & \\
\hline $\begin{array}{l}\text { T. Kiimann } \\
\text { A. Madisson }\end{array}$ & 1888 & Risti & 1 \\
\hline Kokku & $1888 / 1889$ & Pilistvere & 317 \\
\hline
\end{tabular}

Tabel. Mõistatused EKmSi rahvaluulekogudes 1872-1893.

Eesti Kirjameeste Seltsis pandi aastatel 1872-1893 eelkõige Jakob Hurda sihikindla ja süstemaatilise tööga alus eesti rahvaluulekogumisele. Töötati välja printsiibid, mis on vastu pidanud kuni 21 . sajandi alguseni. Need kehtisid ka mõistatuste kogumise kohta.

1. Kogumistöö sai ühe kindla organisatsiooni (hiljem ka asutuste või üksikisiku) üheks põhiliseks tegevusvaldkonnaks.

2. Organisatsioonis hakkas praktilist kogumistööd korraldama üks isik - EKmSis Jakob Hurt, hiljem Jaan Jõgever.

3. Kogumistööks värvati võimalikult paljudest kihelkondadest vabatahtlikud korrespondendid/kaastöölised, kes tundsid kõige paremini folkloorset keskkonda nagu ka folkloori kandjaid - laulikuid ja jutustajaid. 
4. Kohalikel kaastöölistel võis omakorda kujuneda kogujate ring, näideteks C. Allas, F. Matson jt (hilisemal ajal nt E. Tammsoo, paljud kooliõpetajad lastefolkloori kirjapanemise organiseerijatena).

5. Kogumistööle kutsuti avalike üleskutsetega, tulemustest anti aru seltsi koosolekutel ja ajakirjanduses, kogujatega hoiti sidet isikliku kirjavahetuse kaudu.

6. Kogujatele anti raha ja kingiti raamatuid.

7. Saadeti välja esimesed tasustatud stipendiaadid, tavaliselt üliõpilased, kes kogusid peamiselt laule, mõistatusi nende kirjapanekute hulgas ei leidu.

Mõistatused ei olnud Eesti Kirjameeste Seltsi kogumistöös erilisel kohal. Ometi on mõistatusi nimetatud nii üleskutsetes, aruannetes kui ka publitseerimiskavades. Esmajoones pandi rõhk lauludele, ka vanasõnu ja kõnekäände laekus mõistatustest tunduvalt rohkem (rahvalaule - 6403, rahvajutte - 714, vanasõnu (sh kõnekäände) 6636, uskumusi ja kombeid - 1801, vt diagramm) (Mälk 1963: 293).

Rahvaluule põhiliigid EKmSi kogus

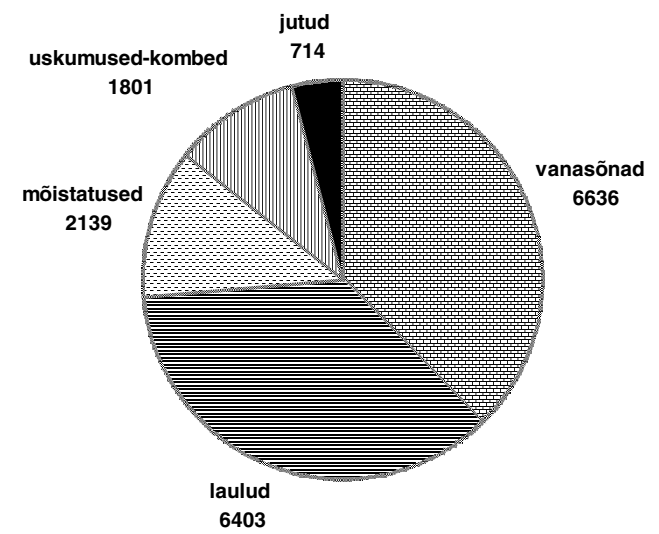




\section{Rein Saukas}

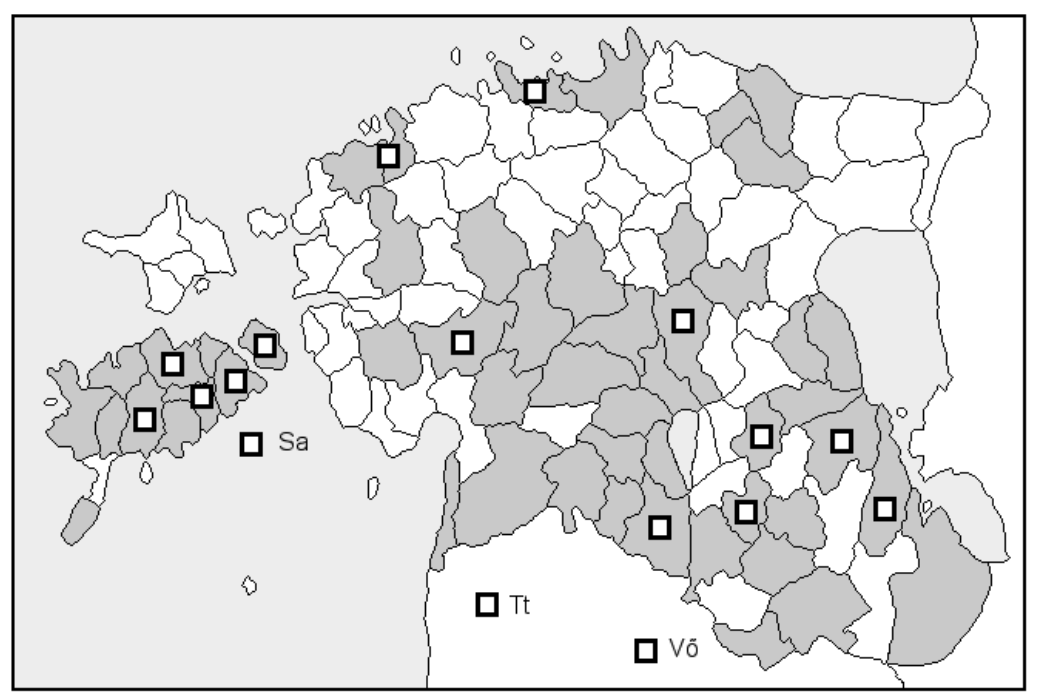

Kaart 1. Rahvaluule (mõistatused tähistatud valgete ruutudega) kogumine EKmSis aastail 1872-1881.

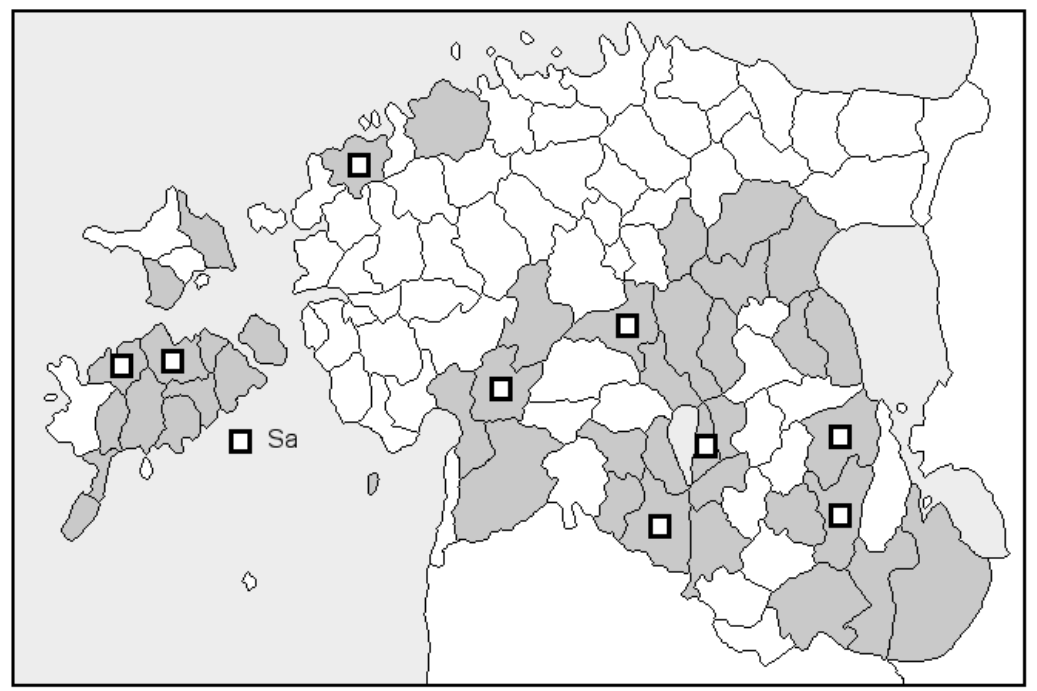

Kaart 2. Rahvaluule (mõistatused tähistatud valgete ruutudega) kogumine EKmSis aastail 1882-1893. 
Mõistatusi saatis 23 nimelist kogujat, üks kandis pseudonüümi ja kolm on jäänud anonüümseks. Tavaliselt jäi mõistatuste saadetis kogujal ainukeseks, korduvalt ja pikema aja vältel on saatnud ainult Villem Mägi. Mõistatused on pärit 14 kihelkonnast, lisaks tekste määratlusega Saaremaa, Pöide?, Võrumaa?, ühe saadetise päritolu on täiesti teadmata. Kõige tihedamini on kogutud Saaremaalt.

Mõistatuste laekumist päritolukihelkondade järgi kajastavad kaardid 1 ja 2 .

Kokku saadeti EKmSi 2139 mõistatust, mis perioodide kaupa jagunevad järgmiselt:

aastad 1872-1875-927,

aastad 1876-1881-516,

aastad 1882-1893-696.

EKmSi laekunud mõistatuste saadetisi iseloomustab

1) üsna autentne materjal, mis sisaldab ka väga lokaalset traditsiooni, mõningast trükiste kasutamist saab täheldada ainult A. Wahlbergil, K. Moksil ja ühel anonüümsel saatjal;

2) tekstid on valdavalt kirjakeeles, murdejoonte märkimine on juhuslik ja ebakorrapärane (murdekeelset tegelikult nii väga ei soovitudki, polnud vastavaid juhiseid, alles 1888. a hakkas J. Hurt nõudma rahvaluule ülesmärkimist murdekeeles);

3) saadetised on paljudel juhtudel varustatud puudulike isiku-, aga eriti kohaandmetega;

4) hilisemale uurijale ja publitseerijale tekitab probleeme ühe ja sama materjali saatmine eri kogujate kätte (J. Jagomann) nagu ka mustandkäsikirjade saatmine seltsi pärast koguja surma (A. Wahlberg). 


\section{Rein Saukas}

\section{Kommentaarid}

${ }^{1}$ Korjandusest EKS $8^{\circ} 1,348-349$ on C. Allas kopeerinud 9 mõistatust oma kogusse H II 45, 661-663.

${ }^{2}$ Seda juhendit nimetab Frido Matson oma kirjas J. Hurdale 26. veebruarist 1877 konkreetseks ajendiks asuda rahvaluulet kirja panema (H I 4, $37)$.

${ }^{3}$ Vt Jakob Jagomann Jakob Hurdale 1904: "Eesti rahva vana vara korjaja elo lugu" (H II 74, 122).

4 Terve korjandus mahub lehekülgedele 381-417.

5 J. Kunderi enda 1887. a juulis üles tähendatud 12 mõistatust jõudsid Eesti Rahvaluule Arhiivi Jaan Leppiku vahendusel alles 1935. a. Kaaskirjast loeme: Saadan Teile [O. Looritsale - R. S.] nüüd paar vana, määrdunud lehekest, mis J. Kunder Holstrest oma käega lühedalt on üles tähendanud (ERA II 116, 373).

${ }^{6}$ Kaaskirjas ajakirja toimetusele (EKS $4^{\circ} 5$, 309-310) teatab J. Melzov: Teie auulise lehele saadan mõne lühikese tükikese avaldamiseks, mis minu aeg on lubanud paberisse panna, ja lisab, et kui leht mõistatusi soovib, siis võin neid küll-küll saata, mis kokku olen korjanud. J. Melzovi mõistatusi Oma Maa ei avaldanud ja rohkem ta neid ka ei saatnud.

${ }^{7}$ Ka P. Nõggese saadetud jutt on avaldatud Oma Maa 6. numbris.

${ }^{8}$ V. Mälk on leidnud ka V. Mägi rahvalaulukirjapanekutest ebatraditsioonilisi värsse või ilustusi (vt lähemalt Mälk 1963: 243-245).

${ }^{9}$ M. Veske kogu ERA kollektsioonide hulgas koosneb köidetest 1-6, lisaks Veske, kad., mis sisaldab K. Krohni koopiaid M. Veske materjalidest.

${ }^{10}$ Mõistatuste akadeemilise väljaande koostajad ei olnud P. Kääri üleskirjutustest teadlikud, sest Eesti Kultuuriloolise Arhiivi käsikirjadest on mõistatusi koondkartoteeki kopeeritud vaid juhuslike leidudena.

${ }^{11}$ Eesti rahvusbibliograafia andmetel ei ole Ermi-nimelist autorit ega kirjastajat.

\section{Lühendid}

$\mathrm{EKmS}=$ Eesti Kirjameeste Selts 
Rein Saukas

\section{Käsikirjad}

EKS = Eesti Kirjameeste Seltsi käsikirjaline rahvaluulekogu (1867-1891), Eesti Rahvaluule Arhiiv

ERA = Eesti Rahvaluule Arhiivi käsikirjaline rahvaluulekogu (1927-1944), Eesti Rahvaluule Arhiiv

H = Jakob Hurda käsikirjaline rahvaluulekogu (1860-1906), Eesti Rahvaluule Arhiiv

EKLA - Eesti Kultuuriloolise Arhiivi käsikirjade kogu

\section{Kirjandus}

Annus, Endel (toim) 1995. Eestikeelne raamat 1851-1900 = Estnisches Buch, 1851-1900 1: A-Q - 2: R-Y. Eesti retrospektiivne rahvusbibliograafia 1. Tallinn: Eesti Teaduste Akadeemia Raamatukogu, nr 31173120.

Avalik kiri kõigile 1978. Eesti Postimehe lisaleht 14; Sakala lisaleht 11; Perno Postimees 16; Neue Dörptsche Zeitung 73.

C. E. Mötleja [= Malm, Carl Eduard] 1878. Mõistatuste raamat: Esimene korjandus. Tallinn: K. E. Malm.

EKmSi protokollid 1873a. Kolmas koosolek: 28. Detsembril 1872, Tartus. Eesti Kirjameeste Seltsi aastaraamat 1873. Tartu, lk 78-80.

EKmSi protokollid 1873b. Neljas koosolek: 13. Juunil 1873, Tartus. Eesti Kirjameeste Seltsi aastaraamat 1873. Tartu, lk 80-82.

EKmSi protokollid 1875a. Eesti Kirjameeste Seltsi protokollid: Vies koosolek: 2. Januaril 1874, Tartus. Eesti Kirjameeste Seltsi aastaraamat 1874. Tartu, lk 71-73.

EKmSi protokollid 1875b. Eesti Kirjameeste Seltsi protokollid: Seitsmes koosolek: 8. Jaanuaril 1875, Tartus. Eesti Kirjameeste Seltsi aastaraamat 1875. Tartu, lk 91-96.

EKmSi protokollid 1875c. Kaheksas koosolek: 26. ja 27. Septembril, Tartus. Eesti Kirjameeste Seltsi aastaraamat 1875. Tartu, lk 96-103.

EKmSi protokollid 1877a. Kümnes koosolek: 15. ja 16. Juunil 1876, Põltsamaal. Eesti Kirjameeste Seltsi aastaraamat 1877. Tartu, lk 69-73.

EKmSi protokollid 1877b. Kaksteistkümnes koosolek: 14. ja 15. Juunil 1977, Tartus. Eesti Kirjameeste Seltsi aastaraamat 1877. Tartu, lk 79-85.

EKmSi finantsaruanne 1879. Välja läinud. Eesti Kirjameeste Seltsi aastaraamat 1879. Tartu, lisa 36. 


\section{Rein Saukas}

EKmSi protokollid 1881a. Eesti Kirjameeste Seltsi protokollid. XXV koosolek Tartus, 20. Januaril 1881. Eesti Kirjameeste Seltsi aastaraamat 1881. Tartu, lisa 1-13.

EKmSi protokollid 1881b. Protokoll XXVII. Koosoleku üle 13. Novembril 1881 Vanemuise Seltsi majas Tartus. Eesti Kirjameeste Seltsi aastaraamat 1881. Tartu, lisa 29-34.

EM 2001-2002 = Hussar, Anne \& Krikmann, Arvo \& Saukas, Rein \& Voolaid, Piret (koost). Eesti mõistatused = Aenigmata Estonica I-II. Monumenta Estoniae Antiquae IV: 1-2. Tartu: Eesti Keele Sihtasutus.

Holtz, Otto Reinhold von 1817. Luggemissed Eestima Tallorahva Moistusse ja Süddame Juhhatamiseks. Tallinn.

Hurt, Jakob 1893. Üheksaskümnes tõine aruanne Eesti vanavara korjamisest ja keelemurrete uurimisest. Olevik 49, 6. detsember.

Hurt, Jakob 1989. Mis lugu rahva mälestustest pidada. Mida rahvamälestustest pidada: Artiklite kogumik. Tallinn: Eesti Raamat 1989, lk 9-25.

Hurt, Jakob 1989a. Eestirahva ajaraamat. Mida rahvamälestustest pidada: Artiklite kogumik. Tallinn: Eesti Raamat, lk 31-35.

Jõgever, Jaan 1886. Hea nõu kooliõpetajatele, kooliõppijatele ja igale teaduse sõbrale. Oma Maa 1, lk 21-23; avaldatud ka Saarlase lisa 9.

Kunder, Juhan 1886. Mõnda Eesti rahva luuletustest. Meelejahutaja 27, lk 214-215; 28, lk 223; 29, lk 230-231.

Mälk, Vaina 1963. Eesti Kirjameeste Seltsi osa eesti folkloristika arengus. Keele ja Kirjanduse Instituudi uurimused 7. Tallinn: Eesti Riiklik Kirjastus.

Põldmäe, Rudolf 1957. Jakob Jagomann ja tema "Räpina kihelkonna ajaraamat". Eesti NSV Teadusete Akadeemia toimetised. Ühiskonnateaduste seeria 6 : 1 , lk 65-73.

R. G. K. [= Kallas, Rudolf Gottfried] 1872. Saaremaalt, kuidas sääl Eesti vana vaimuvara unetamise eest katsutakse hoida, [---]. Eesti Postimees 47, 22. november, lk 1 .

Jahresversammlung der gelehrten estnischen Gesellschaft zu Dorpat am 18. Januar 1875. Sitzungsberichte der Gelehrten Estnischen Gesellschaft zu Dorpat 1875. Dorpat, 1876, lk 1-25.

Sommer, Martin 1883. Viru Eestlaste endistest pulma pruukidest. Eesti Kirjameeste Seltsi aastaraamat 1882. Tartu, lk 69-77.

Wiedemann, Ferdinand Johann 1876. Aus dem inneren und äusseren Leben der Ehsten. St. Petersburg: Keiserliche Akademie der Wissenschaften.

Willmann, Friedrich Wilhelm 1782. Juttud ja teggud, kui ka Monningad Öppetused mis majapiddamisse pärrast tarwis lähtwad. Tallinn: Lindforss. 